University of Nebraska - Lincoln

DigitalCommons@University of Nebraska - Lincoln

USDA National Wildlife Research Center - Staff Publications
U.S. Department of Agriculture: Animal and Plant Health Inspection Service

January 1995

\title{
Abundance of Gulls and Other Birds at Landfills in Northern Ohio
}

Jerrold L. Belant

U.S. Department of Agriculture, Denver Wildlife Research Center

Thomas W. Seamans

U.S. Department of Agriculture, Denver Wildlife Research Center, thomas.w.seamans@aphis.usda.gov

Steven W. Gabrey

U.S. Department of Agriculture, Denver Wildlife Research Center

Richard A. Dolbeer

U.S. Department of Agriculture, Denver Wildlife Research Center

Follow this and additional works at: https://digitalcommons.unl.edu/icwdm_usdanwrc

Part of the Environmental Sciences Commons

Belant, Jerrold L.; Seamans, Thomas W.; Gabrey, Steven W.; and Dolbeer, Richard A., "Abundance of Gulls and Other Birds at Landfills in Northern Ohio" (1995). USDA National Wildlife Research Center - Staff Publications. 136.

https://digitalcommons.unl.edu/icwdm_usdanwrc/136

This Article is brought to you for free and open access by the U.S. Department of Agriculture: Animal and Plant Health Inspection Service at DigitalCommons@University of Nebraska - Lincoln. It has been accepted for inclusion in USDA National Wildlife Research Center - Staff Publications by an authorized administrator of DigitalCommons@University of Nebraska - Lincoln. 


\title{
Abundance of Gulls and Other Birds at Landfills in Northern Ohio
}

\author{
JERROLD L. BELANT, THOMAS W. SEAMANS, STEVEN W. GABREY \\ AND RICHARD A. DOLBEER \\ U.S. Department of Agriculture, Denver Wildlife Research Center, \\ 6100 Columbus Avenue, Sandusky, Ohio 44870
}

\begin{abstract}
We estimated the abundance of birds at three landfills in northern Ohio from May 1991-July 1992 recording 699,350 individuals of 42 species. Gulls (Larus spp.) comprised $94.5 \%$ of the birds recorded followed by European starlings (Sturnus vulgaris, $5.0 \%$ ) and turkey vultures (Cathartes aura, $0.3 \%$ ). Gulls were primarily of two species, ring-billed ( $L$. delawarensis, $74.49 \%$ ) and herring (L. argentatus, $25.50 \%$ ). The mean number of gulls per observation during July-January was at least five times the mean number observed during other months. The combined monthly mean number of gulls at the three landfills peaked in August ( $>4000$ birds), with gulls virtually absent in February. Total numbers, species composition and age composition of gulls varied seasonally in response to breeding, foraging and migratory behavior of local and regional populations. More than $98 \%$ of gulls observed were recorded on or within $30 \mathrm{~m}$ of the ground. A mean of one \pm 17 (SD) gulls per observation were observed soaring at $>300 \mathrm{~m}$ elevation over the landfills. Species composition and seasonal abundance of birds varied considerably among the three landfills, even though they were operated similarly and were in close proximity to each other. To adequately assess the use of landfills by gulls and other birds, studies lasting $\geq 1$ year are required. Furthermore, the results from one landfill cannot necessarily be extrapolated to other landfills in the same region.
\end{abstract}

\section{INTRODUCTION}

Gulls (Larus spp.) frequently have been reported as a hazard to aircraft (Dahl, 1984; Seubert, 1990; Sherigalin, 1990). Waste disposal sites accepting putrescible wastes (hereafter referred to as landfills) often attract birds, especially gulls (Larus spp.; Kihlman and Larsson, 1974; Burger and Gochfeld, 1983; Horton et al., 1983; Greig et al., 1986; Coulson et al., 1987; Patton, 1988). The Federal Aviation Administration issued Order 5200.5 in 1974 to prohibit landfills within $5000 \mathrm{ft}(1.5 \mathrm{~km})$ of runways used by piston-type aircraft and $10,000 \mathrm{ft}(3 \mathrm{~km})$ of runways used by turbine-powered aircraft. In 1990 this order was revised (Order 5200.51) to include landfills from $10,000 \mathrm{ft}(3 \mathrm{~km})$ to 5 miles $(8 \mathrm{~km})$ of runways (Federal Aviation Administration, 1990).

There has been continuing discussion and controversy regarding the minimum distance of landfills from airports. To make informed decisions on landfill sitings and operations with regard to aircraft safety, more information is needed on the extent and pattern of daily bird use (feeding, soaring, loafing) of landfills and the area around landfills (Lake, 1984; McLaren et al., 1984; Risley and Blokpoel, 1984; Southern and Southern, 1984; Forsythe and Austin, 1984). In addition, we know little about the contribution that abundant dependable food at landfills has made to the overall population increases of gulls in many areas of North America (Kadlec and Drury, 1968; Ludwig, 1974; Blokpoel and Tessier, 1986).

Although several studies in Europe have described annual use and seasonal abundance of gulls at landfills (Coulson and Butterfield, 1986; Pons, 1992), there are few quantitative data pertaining to seasonal abundance of gulls at landfills in North America. Patton (1988) 
provided qualitative data on annual abundance of three gull species at landfills in Florida. However, there are currently no comparative data on annual abundance of gulls at landfills in the northern United States. Therefore, our objective was to quantify annual abundance and population fluctuations of gulls and other birds at three landfills in northern Ohio, all within $30 \mathrm{~km}$ of Lake Erie.

\section{STUdy AREA AND METHODS}

We conducted the study at three landfills near Lake Erie in northern Ohio. The Erie County landfill, $7 \mathrm{~km}$ south of Lake Erie and 17-21 km southeast of herring gull (Larus argentatus) nesting colonies on Sandusky Bay (Belant et al., 1993), averaged 222 metric tons of refuse a day, five days per week. The Ottawa County landfill, $2 \mathrm{~km}$ from Lake Erie and $26-30 \mathrm{~km}$ northwest of the nesting colonies, averaged 563 metric tons of refuse per day. The Huron County landfill, $30 \mathrm{~km}$ from Lake Erie and $35-36 \mathrm{~km}$ south of the colonies, averaged 103 metric tons of refuse per day. At each landfill, refuse was spread and compacted throughout the day, then covered with soil at the end of the workday. Each landfill generally had $<0.5$ ha of exposed refuse on any given day. The highest rates of refuse deposition occurred from May to August (115-362 tons/day); rates were 25-39\% lower from January to April.

The number of gulls at the Erie County landfill was estimated, usually twice a day five days per week, at randomly selected times in the morning and afternoon from May 1991 to July 1992. All observations were conducted by experienced personnel who were trained to estimate in similar ways the number of birds present. During each visit, one or two observers used binoculars to count a group of gulls ( $\leq 200$ individuals). The total population of gulls at the landfill on or within $30 \mathrm{~m}$ of the ground was then determined by estimating the number of groups of the given size and multiplying by the group size. We generally conducted total counts when gull populations were $<500$ individuals. Age and species composition of gulls at the landfill was determined by sampling $\geq 10 \%$ of the estimated population with binoculars throughout the entire landfill. Each sampled bird was identified to species, and by age class based on plumage: adult, subadult (1 to 2 or 3-years-old), or hatching year (<1-year-old; Grant, 1986). All gulls hatched during 1991 were classified as subadults during 1992. The number and height of gulls soaring at three ranges of elevation $(31-150 \mathrm{~m}, 151-300 \mathrm{~m},>300 \mathrm{~m})$ were also recorded; elevations were estimated using a range finder. Once the elevation(s) of one or more gulls were known, elevations of other gulls were estimated based upon the known altitude(s) at which gulls were present. When a great difference in soaring altitudes occurred, we often checked our estimates with the range finder. We generally spent 10-30 min during each observation period counting and estimating the population, depending upon the number of gulls present. After completing gull population estimates, these same techniques were used to estimate abundance of all other species, without regard to age classes.

These observation procedures also were used at the Ottawa County and Huron County landfills by the same trained personnel. However, the Ottawa County landfill was checked during the day, at a randomly selected time, once a day, usually three to five days each week from May 1991-July 1992 and the Huron County landfill was checked at a randomly selected time once a day, one to three days each week from June 1991-July 1992.

Data were analyzed using the General Linear Models Procedure (GLM; SAS Inst., Inc. 1988). If significant $(P<0.05)$ differences occurred using GLM, Tukey tests were used to determine which means differed. 


\section{RESUlts}

We recorded 699,350 individuals of 42 species of birds at the three landfills in 958 observation periods (38 species at Erie, 17 at Ottawa, and 21 at Huron; Table 1). Gulls comprised $94.5 \%$ of the birds recorded with European starlings [Sturnus vulgaris (5.0\%)] and turkey vultures [Cathartes aura $(0.3 \%)$ ] the next most abundant birds. The gulls were primarily of two species, ring-billed [L. delawarensis $(74.5 \%)]$ and herring $(25.5 \%)$; great black-backed (L. marinus), glaucous (L. hyperboreus) and laughing (L. atricilla) gulls combined comprised $<0.01 \%$.

The total numbers of gulls varied considerably among landfills and among days and seasons at a landfill. Overall mean numbers of gulls at the Erie County and Ottawa County landfills were six and five times greater, respectively, than the mean number observed at Huron County Landfill (Table 2$)$. There were also differences $(\mathrm{P}<0.01)$ in the monthly mean number of gulls observed at the Erie County $(F=24.01 ; 14$ and $1110 \mathrm{df})$, Huron County $(F=6.14 ; 13$ and $260 \mathrm{df})$, and Ottawa County $(F=45.27 ; 14$ and $458 \mathrm{df})$ landfills. The mean number of gulls per observation during July through January was at least five times the mean number observed during other months (Fig. 1). The number of gulls peaked at all of the landfills in August ( $>4000$ birds), with gulls virtually absent in February.

Overall, ring-billed gulls were more abundant $(\mathrm{P}<0.01)$ than herring gulls at each of the landfills $(F=35.25-148.74$ and $1260-1110 \mathrm{df})$. However, species composition differed $(\mathrm{P}<0.01)$ at all three landfills among months $(F=4.10-27.45 ; 1$ and 13 or 1 and $14 \mathrm{df}$ ). Herring gulls were more abundant than ring-billed gulls from February through June and ring-billed gulls were more abundant than herring gulls from July through January (Fig. 1).

Herring gulls at the landfills from April through December were predominantly adults (Fig. 2). The proportion of subadult herring gulls generally increased during fall and peaked between February and April. Hatching-year herring gulls were first observed during July of both years and generally increased in numbers through December of 1991 .

Age composition of ring-billed gulls among landfills was more variable than that herring gulls. At Erie County, adults were most abundant from August through April whereas subadults were more abundant from May through July in both years (Fig. 3). At Huron County, adults were most abundant from November through January. Except during July 1992, subadults were most abundant between March and August. At Ottawa County landfill, adult ring-billed gulls were more abundant than subadults during all months except May 1991, and April and June 1992. Hatching-year ring-billed gulls were first observed at the landfills during July of both years. Their numbers increased through October or November, then declined by December. At Huron County, hatching-year ring-billed gulls were the most prevalent age class during September and October.

Over $98 \%$ of the gulls observed at the three landfills were on or within $30 \mathrm{~m}$ of the ground during observations. Gulls were observed infrequently ( $\bar{x}=$ one \pm 17 [SD]) soaring at elevations $>300 \mathrm{~m}$ over the landfills (Table 3 ). The number of gulls soaring $>30 \mathrm{~m}$ over a landfill did not differ $(F=0.58 ; 3$ and $954 \mathrm{df} ; \mathrm{P}=0.63)$ for the four 2-h periods from 0800-1600 $\mathrm{h}$. However, there was a greater total mean number of gulls $<30 \mathrm{~m}$ of the ground at the landfills from $1200-1400 \mathrm{~h}$ than from $0800-1000 \mathrm{~h}(F=4.17 ; 3$ and $954 \mathrm{df} ; \mathrm{P}<$ 0.01 ). The number of gulls present during other times of day was similar (Tukey test, $\mathrm{P}>$ 0.05 ; Table 3).

\section{DISCUSSION}

Although 42 bird species were observed at the three landfills, four species (ring-billed and herring gulls, European starling, and turkey vulture) comprised $99.8 \%$ of the birds 
TABLE 1.-Bird species observed at the Erie (570 observations). Huron (144 observations), and Ottawa (244 observations) county landfills

\begin{tabular}{|c|c|c|c|c|c|c|c|c|c|}
\hline \multirow[b]{2}{*}{ Species } & \multicolumn{3}{|c|}{ Erie } & \multicolumn{3}{|c|}{ Huron } & \multicolumn{3}{|c|}{ Ottawa } \\
\hline & $\begin{array}{c}\% \text { of } \\
\text { observation } \\
\text { periods }\end{array}$ & $\begin{array}{l}\text { Estimated } \\
\text { number } \\
\text { observed }\end{array}$ & $\begin{array}{c}\% \text { of } \\
\text { population } \\
<30 \text { m or on } \\
\text { ground }^{a}\end{array}$ & $\begin{array}{c}\% \text { of } \\
\text { observation } \\
\text { periods }\end{array}$ & $\begin{array}{l}\text { Estimated } \\
\text { number } \\
\text { observed }\end{array}$ & $\begin{array}{c}\% \text { of } \\
\text { population } \\
<30 \text { m or on } \\
\text { ground }^{a}\end{array}$ & $\begin{array}{c}\% \text { of } \\
\text { observation } \\
\text { periods }\end{array}$ & $\begin{array}{c}\text { Estimated } \\
\text { number } \\
\text { observed }\end{array}$ & $\begin{array}{c}\% \text { of } \\
\text { population } \\
<30 \mathrm{~m} \text { or on } \\
\text { ground }^{a}\end{array}$ \\
\hline Ring-billed gull & 70 & 347,700 & $>99$ & 49 & 16,800 & 99 & 78 & 119,500 & $>99$ \\
\hline Herring gull & 80 & 115,700 & $>99$ & 43 & 2900 & 100 & 84 & 46,900 & $>99$ \\
\hline Unknown gull & 15 & 9500 & 22 & 7 & 1100 & 10 & 2 & 600 & 1 \\
\hline \multicolumn{10}{|l|}{ American crow } \\
\hline (Corvus brachyrynchos) & & & & 65 & 1040 & $>99$ & & & \\
\hline \multicolumn{10}{|l|}{ House sparrow } \\
\hline (Passer domesticus) & & & & 50 & 1000 & 100 & & & \\
\hline \multicolumn{10}{|l|}{ Common grackle } \\
\hline (Quiscalus quiscula) & & & & & & & 18 & 280 & 100 \\
\hline Other ${ }^{b}$ & 44 & 880 & $>99$ & 41 & 200 & $>99$ & 17 & 70 & 94 \\
\hline
\end{tabular}

${ }^{a}$ Remainder of birds were observed flying or soaring at $>30 \mathrm{~m}$ elevation

${ }^{b}$ Thirty-four species at Erie County, 15 species at Huron County and 13 species at Ottawa County landfills. Complete species lists are available from the authors 
TABLE 2.-Numbers and species composition of herring (HERG) and ring-billed (RBGU) gulls on or within $30 \mathrm{~m}$ of ground at three landfills

\begin{tabular}{lcccccc}
\hline \hline & & \multicolumn{2}{c}{ Mean number of gulls per observation } & & \multicolumn{2}{c}{$\%$ species composition } \\
\cline { 3 - 4 } \cline { 6 - 7 } Landfill & No. of obs. & $\overline{\mathrm{x}}$ & $\mathrm{SD}$ & & HERG & RBGU \\
\hline Erie & 570 & 811 & 1233 & & 25 & 75 \\
Huron & 144 & 136 & 245 & & 15 & 85 \\
Ottawa & 244 & 681 & 746 & & 28 & 72 \\
All landfills & 958 & 1628 & 1462 & & 25 & 75 \\
\hline
\end{tabular}

recorded. The remaining 38 species were present in low numbers and generally were seen flying over the sites. Gulls, European starlings and turkey vultures have frequently been reported to forage at landfills (Forsythe, 1980; Southern and Southern, 1984; Patton, 1988).

Seasonal variations recorded in numbers, species composition and age composition of gulls appear to be related to nesting activities and migration patterns. The presence of herring gulls at the landfills between April and June was low relative to the large nesting population (3250 pairs in 1992) near Lake Erie and within $36 \mathrm{~km}$ of the landfills during that same time of year (Belant $e t a l$., 1993). The low mean numbers of herring gulls observed from April to June can be attributed in part to their diet of primarily fish during this time (Belant et al., 1993). The increase in adults and the presence of hatching-year herring gulls at the landfills in July coincided with the onset of fledging at these nesting colonies (Belant et al., 1993).

Fall migration of hatching-year and subadult herring gulls in the Great Lakes region

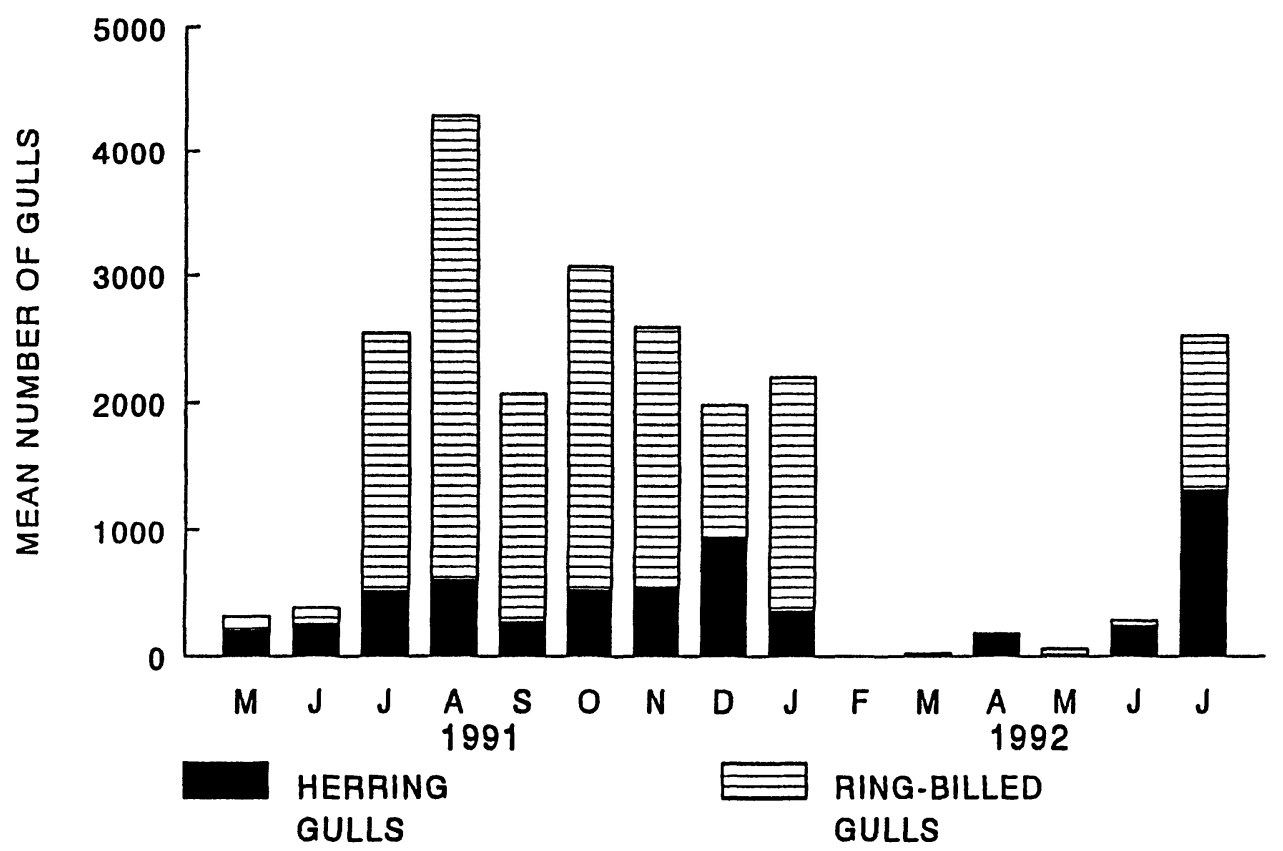

FIG. 1.-Mean number of herring and ring-billed gulls per observation period at three landfills 

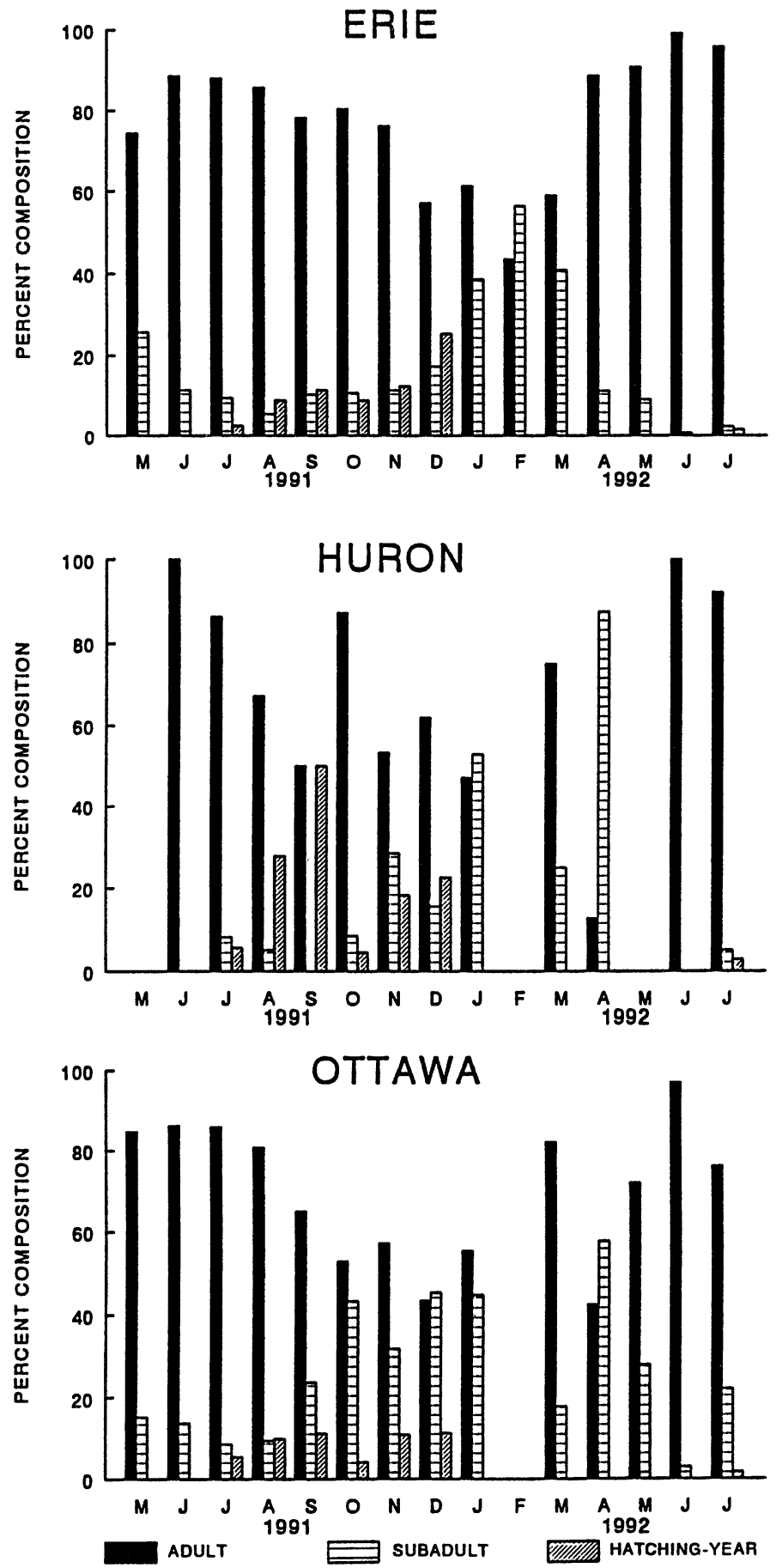

FIG. 2.-Percent age class distributions of herring gulls at three landfills 

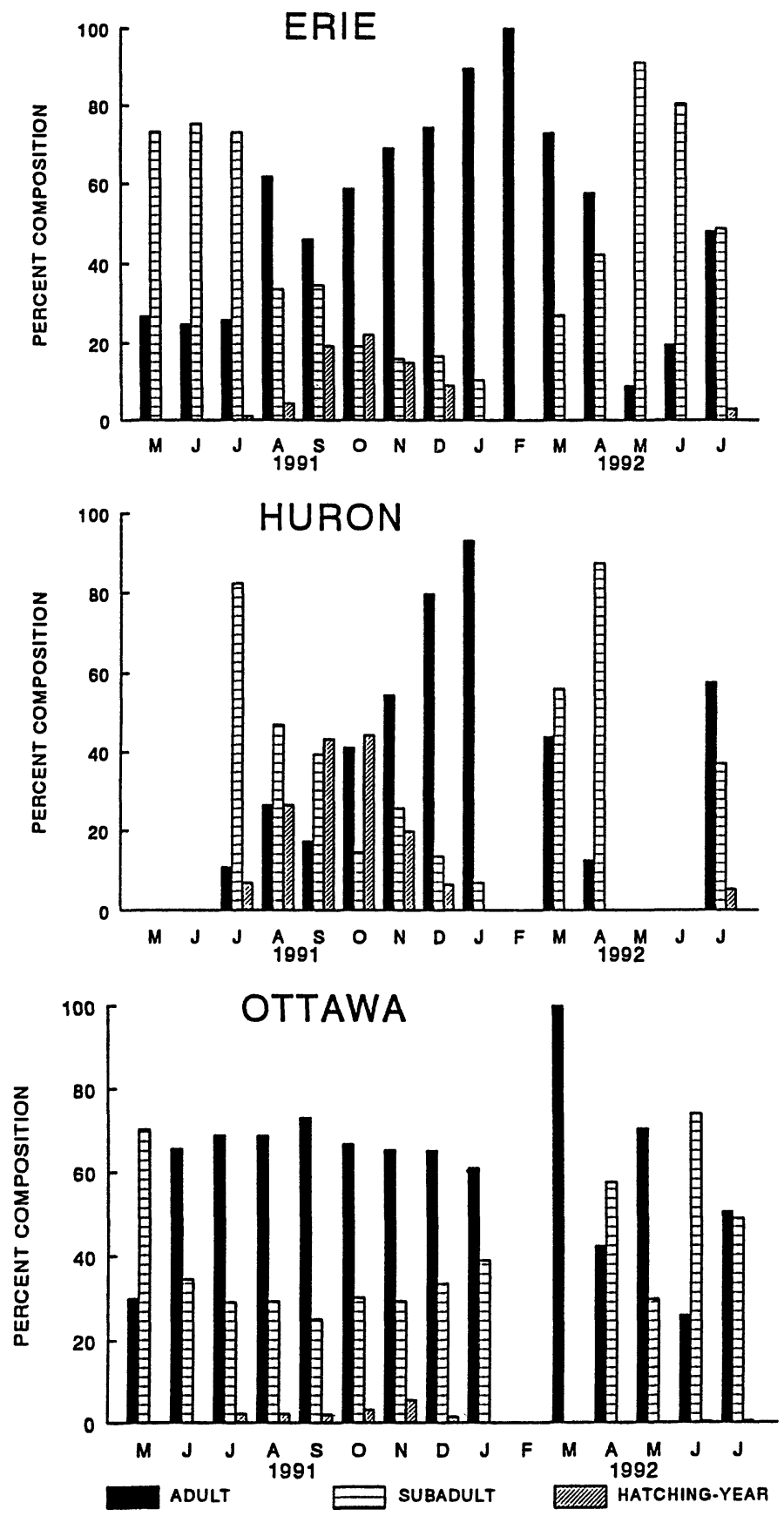

FIG. 3.-Percent age class distributions of ring-billed gulls at three landfills 
TABLE 3.-Mean number of herring and ring-billed gulls per observation period at three landfills by elevation and time of day

\begin{tabular}{lcccccc}
\hline \hline & & \multicolumn{5}{c}{ Mean number of gulls $^{a}$} \\
\cline { 3 - 7 } Time $(\mathrm{h})$ & No. of obs. & $<30 \mathrm{~m}^{b}$ & $31-150 \mathrm{~m}$ & $151-300 \mathrm{~m}$ & $>300 \mathrm{~m}$ & Total \\
\hline $0800-0959$ & 204 & 1350 & 44 & $<1$ & 0 & 1394 \\
$1000-1159$ & 225 & 1841 & 11 & 8 & $<1$ & 1862 \\
$1200-1359$ & 189 & 1985 & 7 & 2 & $<1$ & 1994 \\
$1400-1600$ & 340 & 1474 & 11 & 14 & 2 & 1502 \\
Total & 958 & 1635 & 18 & 7 & 1 & 1661 \\
\hline
\end{tabular}

${ }^{a}$ Sum of means for the 3 landfills

${ }^{b}$ Includes gulls on the ground

begins in November and peaks during December and January. Spring migration is initiated in late February and lasts until April or May (Moore, 1976). This explains the low numbers of subadult herring gulls observed at the landfills between January and March. Moore (1976) also stated that adult herring gulls within the Great Lakes breeding range are yearround residents. The paucity of adult herring gulls observed at the landfills from January to March may be partially explained by increased numbers of gulls observed near areas of greatest urbanization (e.g., Cleveland, Chicago), which provide larger amounts of putrescible waste (Moore, 1976; Dolbeer and Bernhardt, 1986). Also, the total amount of refuse deposited at the landfills in this study was lowest from January to April. Thus, there likely is a reduced amount of putrescible waste available as food.

The large numbers of ring-billed gulls at the landfills between July and January appear related to their regional breeding and wintering populations, and postbreeding dispersal (Southern, 1974; Dolbeer and Bernhardt, 1986; Blokpoel and Scharf, 1991; Blokpoel and Tessier, 1991). Premigratory movements of ring-billed gulls from the Great Lakes begin in July, with migration requiring up to five months (Southern, 1974). Many of these birds congregate along the south shore of the western basin of Lake Erie, which frequently supports the largest early-winter population of ring-billed gulls in North America (Southern, 1974). Although a few migrant ring-billed gulls return to Great Lakes breeding areas in late March, most return during May and June (Southern, 1974). This corresponds with their reoccurrence at the landfills in May.

The nearest nesting population of ring-billed gulls to the landfills is $100 \mathrm{~km}$ west, near Toledo (Scharf, 1978). The incubation period of ring-billed gulls in the southern Great Lakes region occurs from late April through May (Ryder, 1975; Fetterolf, 1979, 1983), with most chicks hatching between late-May and mid-June (Fetterolf, 1983). This corresponds with our first observations of hatching-year birds during July.

Changes in waste management practices can influence gull use at landfills (Patton, 1988). As landfills in this study appeared to be operated similarly, we believe the greater number of gulls observed at the Erie and Ottawa County Landfills compared to the Huron County landfill was a function of their closer proximity to Lake Erie. Because large numbers of herring and ring-billed gulls nest, stage and winter on or adjacent to the Great Lakes (Southern, 1974; Dolbeer et al., 1990; Blokpoel and Scharf, 1991), greater numbers of gulls would be expected at landfills that are closer to these bodies of water.

Because of political boundaries, coastal cities and counties may be unable to locate landfills far enough inland to reduce substantially their use by gulls. For example, herring gulls have been reported to fly $60 \mathrm{~km}$ daily to use landfills (Kilpi, 1984). However, at the Huron 
County Landfill, located more than four times farther inland $(30 \mathrm{~km})$ than the Erie and Ottawa County landfills ( 7 and $2 \mathrm{~km}$, respectively), we observed 80-83\% fewer gulls overall. In addition, concurrent monitoring of radio-tagged nesting herring gulls from the Sandusky Bay colonies suggest minimal use of the Huron County Landfill during incubation and chick-rearing (Belant et al., 1993). Although part of the relative scarcity of gulls observed at the Huron County landfill is likely due to smaller quantities of refuse deposited, increasing the distance of landfills from nesting and staging areas should reduce their use by gulls. Other factors such as habitat and waste management practices, and harassment/control techniques need to be considered during the planning and operating of landfills to further reduce their attractiveness to gulls.

Mixed solid waste landfills can attract large number of birds, especially gulls. However, species composition and seasonal abundance can vary considerably, even among similarly operated landfills in close proximity to each other. Therefore, to adequately assess the use of landfills by gulls and other birds, and the efficacy of management practices to keep these birds away from landfills, studies lasting $\geq 1$ year are required. Furthermore, bird abundance and seasonal dynamics at one landfill cannot necessarily be applied to other landfills, even landfills in close proximity. The monthly and seasonal patterns of local and regional bird populations in relation to location and management practices of landfills must be defined.

Acknowledgments.-We thank personnel at the Erie County, Huron County, and Ottawa County landfills for access to the landfills and providing refuse deposition data; G. E. Bernhardt, S. K. Ickes, R. G. Kozar, K. D. Madaras, M. R. Rutger, D. A. Williams, J. A. Shieldcastle and P. P. Woronecki assisted with observations. H. Blokpoel provided helpful comments for manuscript improvement. Sponsorship and funds for this research were provided by the Federal Aviation Administration, Office of Airports Safety and Standards, Washington, D.C. and Airports Division, Airport Technology Branch, FAA Technical Center, Atlantic City International Airport, New Jersey.

\section{Literature Cited}

Belant, J. L., T. W. Seamans, S. W. Gabrey and S. K. Ickes. 1993. Importance of landfills to nesting herring gulls. Condor, 95:817-830.

BLOKPOEL, H. AND W. C. SCHARF. 1991. Status and conservation of seabirds nesting in the Great Lakes of North America. ICBP Tech. Pub., 11:17-41.

- AND G. D. Tessier. 1986. The ring-billed gull in Ontario: a review of a new problem species. Can. Wildl. Serv. Occas. Pap. 57. 34 p.

AND - 1991. Distribution and abundance of colonial waterbirds nesting in the Canadian portion of the lower Great Lakes system in 1990. Can. Wildl. Serv. Tech. Rep. Ser. No. 117. $16 \mathrm{p}$.

BURGER, J. AND M. GOCHFELD. 1983. Behavior of nine avian species at a Florida garbage dump. Colonial Waterbirds, 6:54-63.

Coulson, J. C. AND J. ButTerfield. 1986. Studies on a colony of colour-ringed herring gulls Larus argentatus. II. Colony occupation and feeding outside the breeding season. Bird Study, 33: 55-59.

,-- N. Duncan AND C. ThOMAs. 1987. Use of refuse tips by adult British herring gulls Larus argentatus during the week. J. Appl. Ecol., 24:789-800.

DAHL, H. 1984. The bird strike situation and its ecological background in the Copenhagen Airport, Kastrup, p. 287-290. In: M. J. Harrison, S. A. Gauthreaux, Jr. and L. A. Abron-Robinson (eds.). Proceedings wildlife hazards to aircraft conference and workshop. U.S. Dep. Transport., Fed. Aviation Admin., Washington, D.C.

DOLBEER, R. A. AND G. E. BERNHARDT. 1986. Early winter population trends of gulls on western Lake Erie, 1950-1984. Am. Birds, 40:1097-1102.

P. P. Woronecki, T. W. Seamans, B. N. Buckingham and E. C. Cleary. 1990. Herring gulls, Larus argentatus, nesting on Sandusky Bay, Lake Erie, 1989. Ohio J. Sci., 90:87-89. 
Federal Aviation Administration. 1990. Order 5200.51. Waste disposal sites on or near airports. U.S. Dep. Trans., Fed. Aviation. Admin., Washington, D.C. 3 p.

FetTEROLF, P. M. 1979. Nocturnal behavior of Ring-billed Gulls during the early incubation period. Can. J. Zool., 57:1190-1195.

1983. Effects of investigator activity on Ring-billed Gull behavior and reproductive performance. Wilson Bull., 95:23-41.

ForsYTHE, D. M. 1980. Attractiveness of shredded garbage to gulls and other avian species potentially dangerous to aircraft. Final Rep., Tyndall Air Force Base, Florida. 97 p.

AND T. W. AusTiN. 1984. Effectiveness of an overhead wire barrier system in reducing gull use at the BFI Jedburg sanitary landfill, Berkeley and Dorchester counties, South Carolina, p. 253263. In: M. J. Harrison, S. A. Gauthreaux, Jr. and L. A. Abron-Robinson (eds.). Proceedings wildlife hazards to aircraft conference and workshop. U.S. Dep. Transport., Fed. Aviation Admin., Washington, D.C.

Grant, P. J. 1986. Gulls: a guide to identification, 2nd ed. Buteo Books, Vermillion, South Dakota. $352 \mathrm{p}$.

Greig, S. A., J. C. Coulson And P. Monoghan. 1986. A comparison of foraging at refuse tips by three species of gull (Laridae). J. Zool. Lond., (A) 210:459-472.

Horton, N., T. BRough AND J. B. A. Rochard. 1983. The importance of refuse tips to gulls wintering in an inland area of south-east England. J. Appl. Ecol., 20:751-765.

Kadlec, J. A. AND W. H. Drury, Jr. 1968. Structure of the New England Herring Gull population. Ecology, 49:644-675.

KIHLMAN, J. AND L. LARSSON. 1974. On the importance of refuse dumps as a food source for wintering Herring Gulls Larus argentatus Pont. Ornis Scand., 5:63-70.

KILPI, M. 1984. Seasonal movements and dispersal in Finnish Herring Gulls Larus argentatus. Ann. Zool. Fennici., 21:253-257.

LAKE, D. W. 1984. Airport bird hazards associated with solid waste disposal facilities, p. 219-230. In: M. J. Harrison, S. A. Gauthreaux, Jr. and L. A. Abron-Robinson (eds.). Proceedings wildlife hazards to aircraft conference and training workshop. U.S. Dep. Transport., Fed. Aviation Admin., Washington, D.C.

LudwiG, J. P. 1974. Recent changes in the Ring-billed Gull population and biology in the Laurentian Great Lakes. Auk, 91:575-594.

MCLAREN, M. A., R. E. HARRIS AND W. J. RichaRdSON. 1984. Effectiveness of an overhead wire barrier in deterring gulls from feeding at a sanitary landfill, p. 241-251. In: M. J. Harrison, S. A. Gauthreaux, Jr. and L. A. Abron-Robinson (eds.). Proceedings wildlife hazards to aircraft conference and training workshop. U.S. Dep. Transport., Fed. Aviation Admin., Washington, D.C.

MOORE, F. R. 1976. The dynamics of seasonal distribution of Great Lakes Herring Gulls. Bird-Banding, 57:141-159.

PatTon, S. R. 1988. Abundance of gulls at Tampa Bay landfills. Wilson Bull., 100:431-442.

PoNs, J. 1992. Effects of changes in the availability of human refuse on breeding parameters in a herring gull Larus argentatus population on Brittany, France. Ardea, 80:143-150.

RISLEY, G. AND H. BLOKPOEL. 1984. Evaluation of effectiveness of bird-scaring operations at a sanitary landfill site near CFB Trenton, Ontario, Canada, p. 265-273. In: M. J. Harrison, S. A. Gauthreaux, Jr. and L. A. Abron-Robinson (eds.). Proceedings wildlife hazards to aircraft conference and training workshop. U.S. Dep. Transport., Fed. Aviation Admin., Washington, D.C.

RYDER, J. P. 1975. Egg-laying, egg size, and success in relation to immature-mature plumage of Ringbilled Gulls. Wilson Bull., 87:534-542.

SAS INSTITUTE, INC. 1988. SAS/STAT user's guide, release 6.03 edition. SAS Inst., Inc., Cary, NC. 1028 p.

SCHARF, W. C. 1978. Colonial birds nesting on man-made and natural sites in the U.S. Great Lakes. U.S. Dep. Int., Fish and Wildl. Serv., FWS/OBS-78/15, Washington, D.C. 128 p.

SEUBERT, J. L. 1990. Reducing gull hazards to aviation by controlling nesting populations. Bird Strike Committee Europe, 20:613-642.

SHERIGAlin, J. E. 1990. Bird strike analysis in Estonia 1951-1988. Bird Strike Committee Europe, 20:183199. 
Southern, W. E. 1974. The annual range of Ring-billed Gulls in the eastern United States: with comments on potential bird/aircraft collision problems, p. 149-190. In: S. A. Gauthreaux (ed.). A conference on the biological aspects of the bird/aircraft collision problem. Clemson Univ., Clemson, NC.

AND L. K. SOUTHERN. 1984. Successful control of gulls and other birds at a sanitary landfill, p. 231-240. In: M. J. Harrison, S. A. Gauthreaux, Jr. and L. A. Abron-Robinson (eds.). Proceedings wildlife hazards to aircraft conference and training workshop. U.S. Dep. Transport., Fed. Aviation Admin., Washington, D.C. 